\title{
Proliferation of hydrocarbon-degrading microbes at the bottom of the Mariana Trench
}

Jiwen Liu ${ }^{1,2 \dagger}$, Yanfen Zheng ${ }^{1 \dagger}$, Heyu Lin ${ }^{1}$, Xuchen Wang ${ }^{3}$, Meng Li ${ }^{4}$, Yang Liư ${ }^{4}$, Meng Yü ${ }^{3}$, Meixun Zhao ${ }^{2,3}$, Nikolai Pedentchouk ${ }^{5}$, David J. Lea-Smith', Jonathan D. Todd ${ }^{6}$, Clayton R. Magill', Wei-Jia Zhang ${ }^{8}$, Shun Zhou', Delei Song ${ }^{1}$, Haohui Zhong ${ }^{1}$, Yu Xin ${ }^{2,3}$, Min Yu ${ }^{1,2}$, Jiwei $\operatorname{Tian}^{9,10^{*}}$ and Xiao-Hua Zhang ${ }^{1,2^{*}}$

\begin{abstract}
Background: The Mariana Trench is the deepest known site in the Earth's oceans, reaching a depth of $\sim 11,000 \mathrm{~m}$ at the Challenger Deep. Recent studies reveal that hadal waters harbor distinctive microbial planktonic communities. However, the genetic potential of microbial communities within the hadal zone is poorly understood.

Results: Here, implementing both culture-dependent and culture-independent methods, we perform extensive analysis of microbial populations and their genetic potential at different depths in the Mariana Trench.

Unexpectedly, we observed an abrupt increase in the abundance of hydrocarbon-degrading bacteria at depths > $10,400 \mathrm{~m}$ in the Challenger Deep. Indeed, the proportion of hydrocarbon-degrading bacteria at $>10,400 \mathrm{~m}$ is the highest observed in any natural environment on Earth. These bacteria were mainly Oleibacter, Thalassolituus, and Alcanivorax genera, all of which include species known to consume aliphatic hydrocarbons. This community shift towards hydrocarbon degraders was accompanied by increased abundance and transcription of genes involved in alkane degradation. Correspondingly, three Alcanivorax species that were isolated from 10,400 m water supplemented with hexadecane were able to efficiently degrade $n$-alkanes under conditions simulating the deep sea, as did a reference Oleibacter strain cultured at atmospheric pressure. Abundant $n$-alkanes were observed in sinking particles at 2000, 4000, and $6000 \mathrm{~m}$ (averaged $23.5 \mu \mathrm{g} / \mathrm{gdw}$ ) and hadal surface sediments at depths of $10,908,10,909$, and $10,911 \mathrm{~m}$ (averaged $2.3 \mu \mathrm{g} / \mathrm{gdw}$ ). The $\delta^{2} \mathrm{H}$ values of $n-C_{16 / 18}$ alkanes that dominated surface sediments at near $11,000-\mathrm{m}$ depths ranged from -79 to $-93 \%$, suggesting that these sedimentary alkanes may have been derived from an unknown heterotrophic source.
\end{abstract}

Conclusions: These results reveal that hydrocarbon-degrading microorganisms are present in great abundance in the deepest seawater on Earth and shed a new light on potential biological processes in this extreme environment.

Keywords: Challenger Deep, Mariana Trench, Hadal water, Metagenomics, Microbial community, Hydrocarbon degradation, Hydrocarbon biosynthesis

\footnotetext{
* Correspondence: xhzhang@ouc.edu.cn; tianjw@ouc.edu.cn

† Jiwen Liu and Yanfen Zheng contributed equally to this work.

${ }^{9}$ Key Laboratory of Physical Oceanography, Ministry of Education, Ocean

University of China, Qingdao 266100, China

${ }^{1}$ MOE Key Laboratory of Marine Genetics and Breeding, College of Marine

Life Sciences, Ocean University of China, Qingdao 266003, China

Full list of author information is available at the end of the article
}

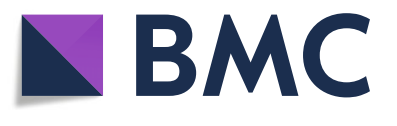

(c) The Author(s). 2019 Open Access This article is distributed under the terms of the Creative Commons Attribution 4.0 International License (http://creativecommons.org/licenses/by/4.0/), which permits unrestricted use, distribution, and reproduction in any medium, provided you give appropriate credit to the original author(s) and the source, provide a link to the Creative Commons license, and indicate if changes were made. The Creative Commons Public Domain Dedication waiver (http://creativecommons.org/publicdomain/zero/1.0/) applies to the data made available in this article, unless otherwise stated. 


\section{Background}

The hadal zone $(6000-11,000 \mathrm{~m})$ is the deepest part of the marine environment and is composed almost exclusively of trenches. Hadal zone planktonic microbial communities have recently been investigated in the Mariana [1-3], Puerto Rico [4], Japan [5], and Kermadec Trenches [6] due to rapid technological progress in deep-sea sampling. The hadal and abyssal (4000-6000 m) waters differ significantly in their micro- and macro-community compositions [1, 5, 7]. Specifically, heterotrophic Gammaproteobacteria and Bacteroidetes are dominant in the hadal ocean, compared to Thaumarchaeota in the abyssal ocean $[1,5$, $6]$. There are only a few depth profile studies of microbial communities in the hadal zone, and thus, little is known of the variability in community composition in this unique environment. In the Challenger Deep of the Mariana Trench, Nunoura et al. demonstrated via $16 \mathrm{~S}$ rRNA gene sequencing that Gammaproteobacteria were the dominant class at $10,257 \mathrm{~m}$, comprising $62.7 \%$ of the total microbial population, compared to $21.6 \%$ and $1.7 \%$ at 9000 and $7998 \mathrm{~m}$, respectively [1]. Moreover, Oceanospirillales comprised $78.1 \%$ of the total Gammaproteobacteria population at $10,257 \mathrm{~m}$, unlike at $9000 \mathrm{~m}$ where Pseudomonadales dominated. Tarn et al. also confirmed the dominance of Gammaproteobacteria in both the Challenger $(\sim 10,918 \mathrm{~m})$ and Sirena $(\sim$ $10,667 \mathrm{~m})$ Deeps of the Mariana Trench, using $16 \mathrm{~S}$ rRNA gene sequencing [2]. The drivers for this major microbial community shift at depths $>10,000$ $\mathrm{m}$ are undetermined, since studies analyzing the genetic potential of microbes [8] and their abundance at the genus and species level at these depths are limited.

To address these knowledge gaps, we conducted the most detailed analysis to date of microbial populations and functional capacities in the Mariana Trench water samples from different depths by metagenome sequencing, 16S rRNA gene amplicon, and gene probe analyses. An unexpected enrichment for hydrocarbon-degrading bacteria, along with an increase in the abundance and transcription of hydrocarbon-degrading genes, was found at depths near the trench bottom $(10,400 \mathrm{~m}$ and 10,500 $\mathrm{m})$. Based on this information, we experimentally tested and confirmed the hydrocarbon degradation activity of bacterial strains isolated from $10,400 \mathrm{~m}$ water supplemented with hexadecane under conditions simulating the deep ocean. Stable hydrogen isotope analysis of surface sediments at the bottom of the trench suggests that $n-C_{16 / 18}$ alkanes, the dominant hydrocarbons in these samples, are derived from an unknown biological source, and may support hydrocarbon-degrading microbial populations.

\section{Results and discussion}

\section{Microbial communities vary throughout the Mariana} Trench water column

To determine the vertical distribution of microbial populations in the Challenger Deep, shotgun metagenome sequencing and 16S rRNA gene amplicon analyses were performed on free-living $(0.22-3 \mu \mathrm{m}) \quad(\mathrm{FL})$ and particle-associated $(>3 \mu \mathrm{m})$ (PA) communities collected from surface waters and from depths of $4000 \mathrm{~m}, 9600 \mathrm{~m}$, $10,400 \mathrm{~m}$, and 10,500 $\mathrm{m}$ (Additional file 1: Table S1 and Figure S1). Also, environmental analysis was performed on samples collected from 4 to $8320 \mathrm{~m}$, which demonstrated that hadal and abyssal waters shared many comparable physiochemical factors, including temperature, salinity, oxygen, and nutrients (Additional file 1: Table S2).

Quantitative PCR assays showed that the 16S rRNA gene copy numbers decreased significantly from 0 $\left(7.73 \times 10^{7}\right.$ copies/L) to $4000 \mathrm{~m}\left(1.21 \times 10^{7}\right.$ copies/L), but then increased with depth to $7.43 \times 10^{7}, 7.58 \times 10^{7}$, and $7.82 \times 10^{7}$ copies/L at $9600,10,400$, and $10,500 \mathrm{~m}$, respectively (Additional file 1: Figure S2). Similarly, Nunoura et al. showed that the abundance of $16 \mathrm{~S}$ rRNA gene decreased along with depth before $6000 \mathrm{~m}$ but then increased slightly from $6000 \mathrm{~m}$ to $10,257 \mathrm{~m}$ except for $9000 \mathrm{~m}$ [1]. In this study, the increase of $16 \mathrm{~S}$ rRNA gene copy number in trench bottom water compared to 4000 $\mathrm{m}$ may be due to increased Gammaproteobacteria populations (see below), which harbor $\sim 5.7$ copies of $16 \mathrm{~S}$ rRNA gene on average, far higher than other Proteobacteria [9], suggesting that $16 \mathrm{~S}$ rRNA gene copy number is not always a good proxy of cell number.

Taxonomic profiling of metagenomic data based on the NCBI-nr database revealed that bacteria accounted for the majority of the population at all depths in both FL and PA samples, compared to archaea and eukaryotes (Additional file 1: Figure S3a). As expected, Proteobacteria, particularly Alphaproteobacteria and Gammaproteobacteria, were the predominant organisms at all depths, whereas Cyanobacteria were relatively abundant only in surface water, accounting for $13.9 \%$ and $7.3 \%$ of the FL and PA samples, respectively (Additional file 1: Figure S3b and 3c). The relative abundance of Gammaproteobacteria increased with depth from $21.3 \%$ at $0 \mathrm{~m}$ to $31.3 \%$ at $4000 \mathrm{~m}, 38.4 \%$ at $9600 \mathrm{~m}$, and $49.2 \%$ at both $10,400 \mathrm{~m}$ and 10,500 $\mathrm{m}$ (Additional file 1: Table S3). Similar to Nunoura et al. [1], the relative abundance of Oceanospirillales increased significantly $(P<0.01)$ in the two near bottom water (NBW; $\sim 300-400 \mathrm{~m}$ from the seafloor) samples, comprising $61.4 \%$ of the gammaproteobacterial genes (5.6-fold increase compared to 9600 $\mathrm{m})$ (Fig. 1a). This dominance of Oceanospirillales in NBW was confirmed by analyses of $16 \mathrm{~S}$ rRNA gene recovered from both the metagenomic and amplicon 


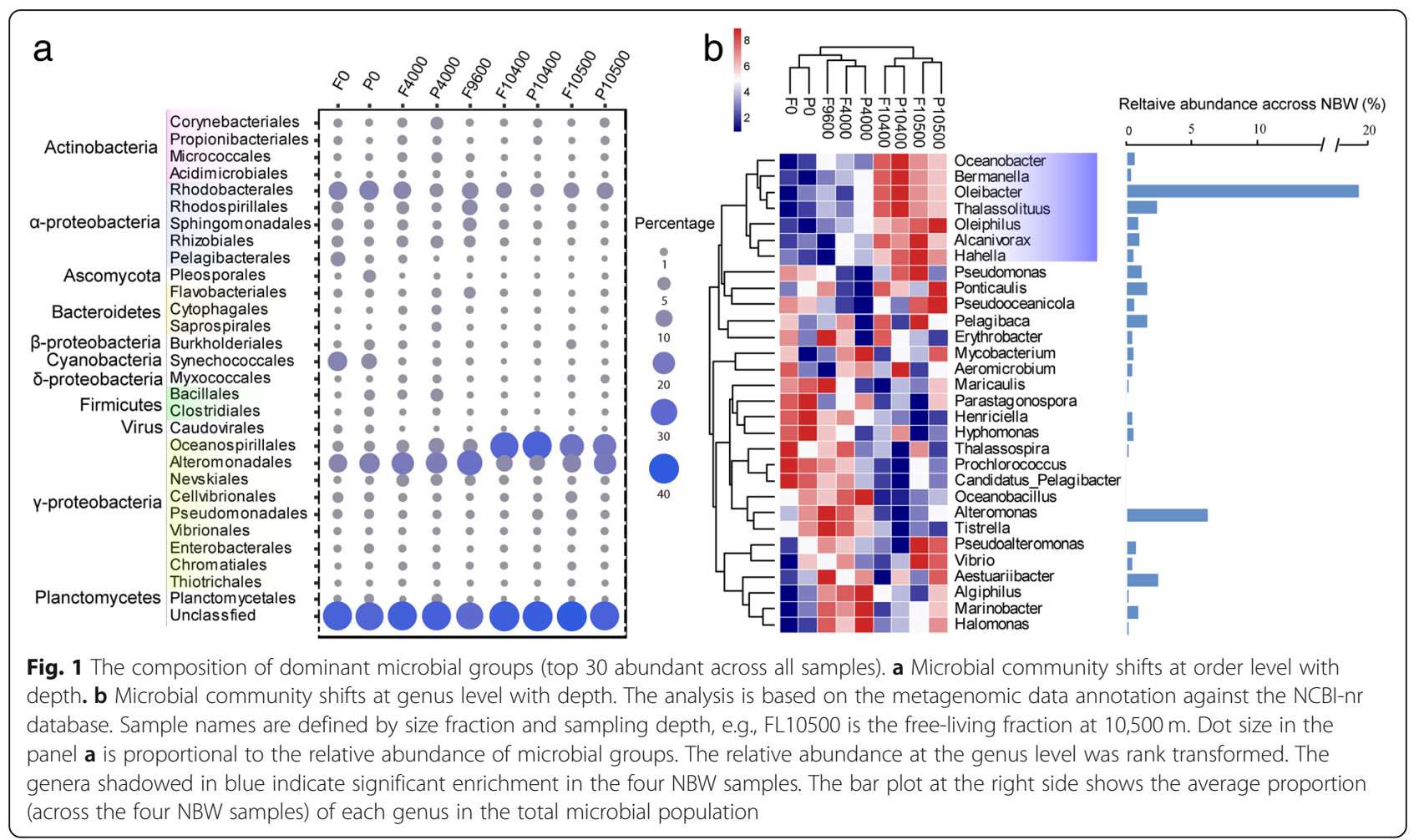

sequencing (Additional file 1: Figure S4), suggesting that a bacterial niche boundary exits at that depth. Several bacterial lineages such as Pelagibacterales differed in relative abundance among different methods used (Additional file 1: Figure S4). Such differences may have resulted from biases in PCR amplification, variation in gene copy number, and genome size [10].

Next, we analyzed the genus-level composition to identify the genera that are significantly enriched in NBW samples. According to the metagenomic data annotated against the NCBI-nr database, seven genera were significantly more abundant in NBW than at other depths $(P<0.05)$ (Fig. 1b). All belonged to the order Oceanospirillales and included Oleibacter (19.5 $\pm 6.5 \%)$, Thalassolituus (2.5 $\pm 0.7 \%)$, Alcanivorax (1.0 $\pm 0.4 \%)$, Oleiphilus (0.9 $\pm 0.7 \%)$, Oceanobacter $(0.6 \pm 0.2 \%)$, Hahella $(0.5 \pm 0.4 \%)$, and Bermanella $(0.3 \pm 0.1 \%)$. $16 \mathrm{~S}$ rRNA gene amplicon analysis also confirmed the predominance of Oleibacter in NBW $(37.8 \pm 8.2 \%)$. This is the first environment where Oleibacter has been reported as the most abundant genus.

\section{Oceanospirillales species encode genes involved in alkane degradation}

To explore the genetic potential in Oceanospirillales that dominate the NBW environment, we compared the metagenomic data against the COG and KEGG databases. The NBW harbored a significantly higher abundance of genes encoding cell motility proteins compared to other depths $(P<0.05)$ (Fig. 2 and Additional file 1 : Figure S5). Predominant among these were genes encoding methyl-accepting chemotaxis proteins (MCP) and type IV pilus assembly genes that function in cell adhesion and twitching motility [11] (Additional file 1: Figure S6), which were mainly attributed to Oleibacter (Additional file 1: Figure S7), a genus which includes species known to degrade hydrocarbons [12, 13]. MCPs have been found to play an important role in sensing various substrates including alkanes [14] and thus may facilitate hydrocarbon degradation by Oleibacter species. MCP and pilus genes were highly transcribed in microbial populations following the Deepwater Horizon oil spill $[15,16]$, further supporting a key role for these genes in microbial hydrocarbon degradation. NBW harbored a lower abundance of genes related to carbohydrate and protein metabolism (COG E and G; Fig. 2), as well as genes involved in the cycling of carbon and sulfur (Additional file 1: Figure S8), suggesting the microbial population in NBW might utilize alternative carbon sources.

To predict hydrocarbon degradation pathways in the abundant NBW Oceanospirillales bacteria described above, we constructed 43 high-quality genomic bins, hereafter referred to as metagenome assembled genomes (MAGs), from the combined contigs of the four NBW samples with a contaminant threshold of $10 \%$ and a completeness threshold of $80 \%$. These include 33 Proteobacteria and three Actinobacteria MAGs; the former contain 19 Alpha-, nine Gamma-, and five 


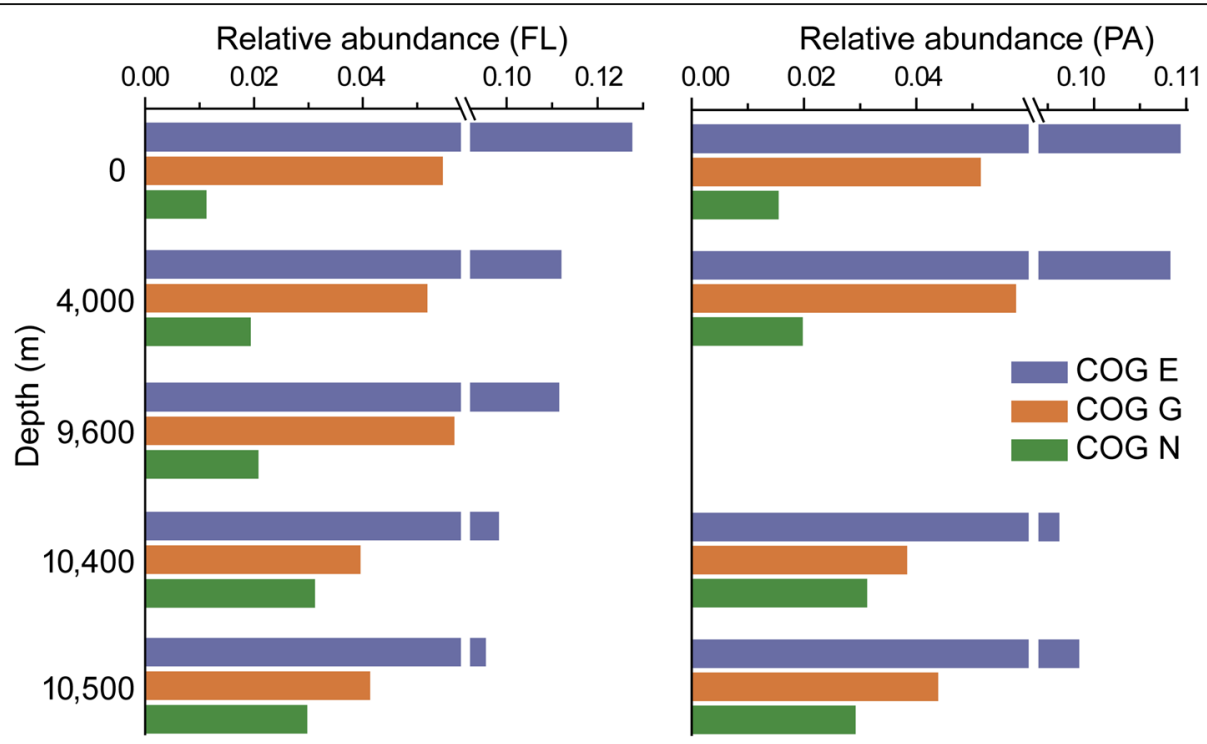

Fig. 2 The relative abundance of three major COG categories related to amino acid transport and metabolism (E), carbohydrate transport and metabolism (G), and cell motility (N). FL, free living; PA, particle associated

Deltaproteobacteria MAGs (Additional file 1: Table S4). Five of the Gammaproteobacteria MAGs, termed MAG 01 (completeness 90.8\%), 78 (completeness 87.7\%), 5.60 (completeness 83.2\%), 12 (completeness 93.2\%), and 156 (completeness 97.8\%), are related to Oceanospirillales. The first three MAGs $(01,78$, and 5.60) are phylogenetically similar to Oleibacter, while the latter two are similar to Alcanivorax and Oleiphilus, respectively. The three Oleibacter MAGs (01, 78, and 5.60) showed an average nucleotide identity of $74.7 \%$ to each other, and $98.6 \%$, $77.2 \%$, and $73.6 \%$ to Oleibacter marinus DSM 24913, respectively. Strain DSM 24913 is a hydrocarbonoclastic bacterium isolated from a crude oil enrichment of Indonesian seawater [12] and the only cultured species available in this genus. Our analyses suggest that MAG 01, 78, and 5.60 represent different Oleibacter species, and MAG 01 is affiliated to $O$. marinus. This was further verified by the high $16 \mathrm{~S}$ rRNA gene sequence similarity $(99.0 \%)$ between MAG 01 and O. marinus DSM 24913. Mapping raw reads to the MAGs showed that MAG 01 was the dominant Oleibacter clade in NBW; its relative abundance was the highest among all MAGs and accounted for 11.6 $\pm 2.4 \%$ of all NBW reads (Additional file 1: Figure S9). These five Oceanospirillales MAGs possess predicted pathways for both medium-chain alkane 1-monooxygenase (AlkB) and long-chain alkane monooxygenase (AlmA)-mediated alkane degradation, for cyclohexane degradation, MCP, and most other chemotactic genes (Fig. 3). Thus, metagenomic predictions suggest that Challenger Deep NBW Oceanospirillales bacteria can metabolize medium-chain, long-chain, and some cyclic hydrocarbons and that such molecules may be important sources of carbon and/or energy in such environments.
To the best of our knowledge, the proportion of Oceanospirillales-derived alkane degraders in NBW $(\sim 20 \%$ in the metagenome and $\sim 38 \%$ in the $16 \mathrm{~S}$ rRNA gene amplicon; Additional file 1: Figure S4a and c) is higher than in any other natural environments observed on Earth. However, the predominance of Oceanospirillales, along with $\mathrm{MCP}$, alkB, and type IV pilus assembly genes in NBW, resembles the situation (dominant microbial communities and functional genes) in the Deepwater Horizon spill (DWH) [15-19], suggesting that the microorganisms in these two distinct environments most likely share similar hydrocarbon-degrading pathways. However, the predominant DWH Oceanospirillales showed high sequence similarity to Candidatus Bermanella macondoprimitus and/or Candidatus Oceanospirillales desum [20, 21]. Although O. marinus was detected in $n$-hexadecane enrichments using water collected from oil plume at $1000 \mathrm{~m}$ after the DWH, it only represented $3 \%$ of the total sequences [22].

\section{Abundance and expression of alkane degradation genes increase in near bottom waters}

The data above suggest that microbial populations in NBW have the potential to degrade hydrocarbons. To test this, we first investigated the abundance of putative hydrocarbon-degrading genes at different water depths (Fig. 4). Interestingly, the relative abundance of genes encoding AlkB, AlmA (Fig. 4a), and several enzymes for sensing and transporting alkanes (Additional file 1: Figure S10) increased significantly in NBW compared to other water depths. The absolute abundance of alkB and $\operatorname{alm} A$ and the proportion of microbial cells possessing them exhibited similar trends (Additional file 1: Figure 


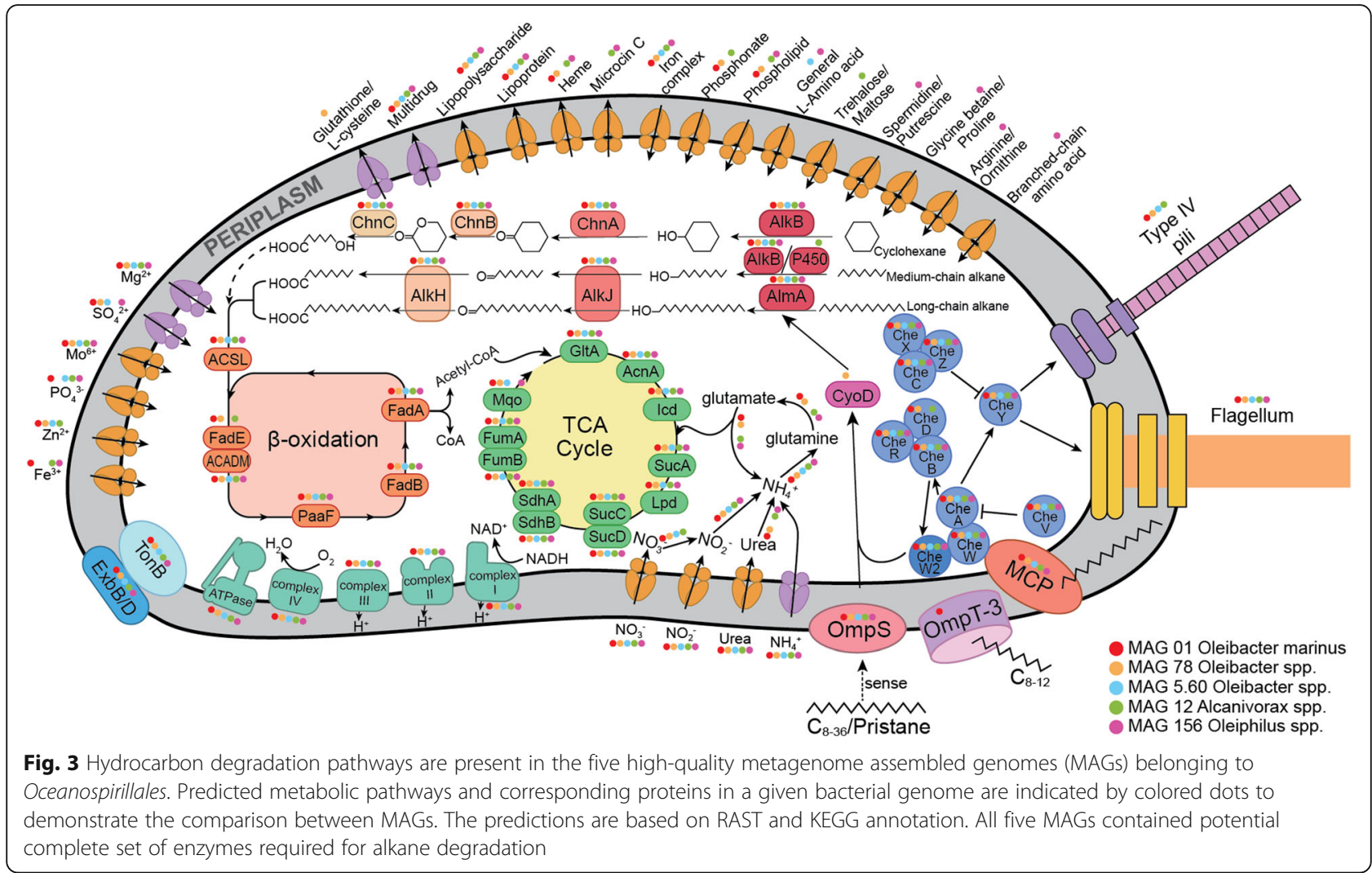

S11). These numbers displayed positive relationships with the relative abundance of Oceanospirillales $(r>$ $0.85, P<0.01$ ), notably Oleibacter (Fig. $4 \mathrm{~b}$ and Additional file 1: Table S5). The increase of $\operatorname{alkB}$ and $\operatorname{almA}$ in NBW was similar to that of MCP (Additional file 1: Figure S6). The abundance of the other known aliphatic hydrocarbon degradation genes was not statistically different among samples from different depths (Fig. 4a). In addition, many aromatic hydrocarbon degradation genes (e.g., for catechol, protocatechuate and gentisate metabolism) were lower in NBW than in other water depths (Additional file 1: Figure S12). Overall, this suggests that alkanes are the main hydrocarbon source utilized by Oceanospirillales species.

To determine whether increases in the transcription of alkB and $\operatorname{alm} A$ corelate with their gene abundance, we

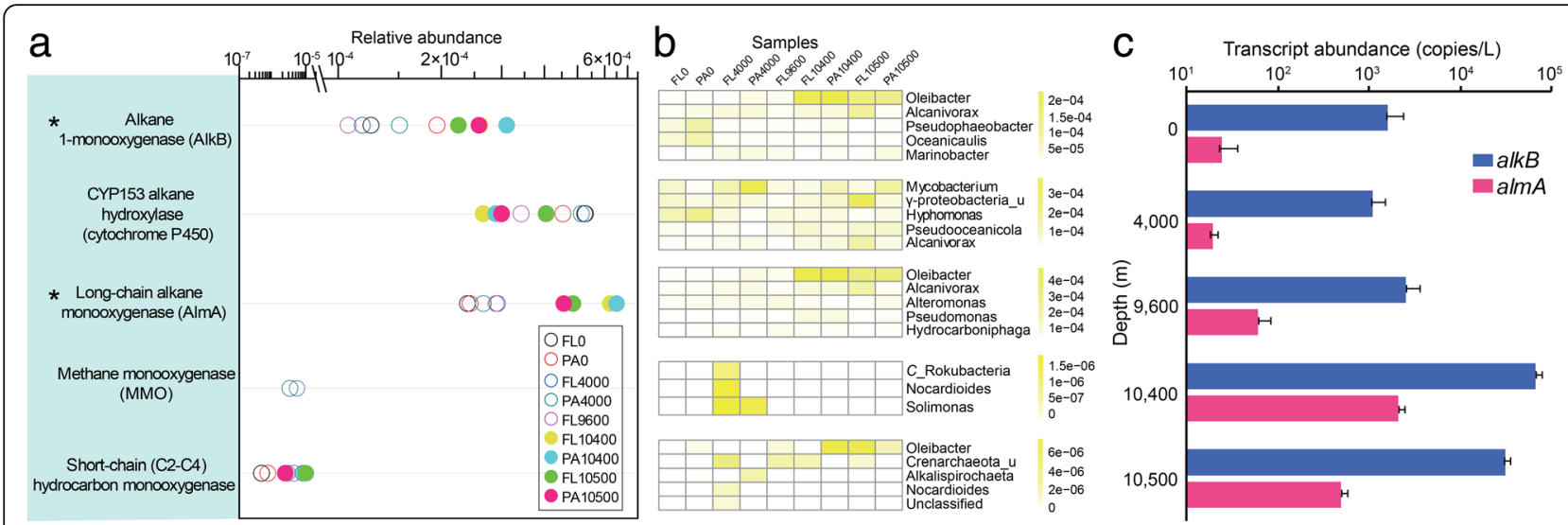

Fig. 4 The relative abundance and expression of genes associated with aliphatic hydrocarbon degradation increase in NBW. a The relative abundance of genes at different depths. b The top five affiliated genera of each gene are shown in the heat map. $\mathbf{c}$ Transcript abundance of alkB and almA in free-living samples from different depths. Asterisks in panel a indicate statistically significant difference in gene abundance between the two zones 
performed RT-qPCR on 0 , 4000, 9600, 10,400, and $10,500 \mathrm{~m}$ samples. $A l k B$ and $\operatorname{alm} A$ genes were highly transcribed in NBW compared to 0,4000 , and $9600 \mathrm{~m}$ (up to 42, 61, 26 and 86, 109, 34-fold increased, respectively) (Fig. 4c), and $81.5-100 \%$ of transcripts were from Oleibacter. This further supports the hypothesis that Oceanospirillales species are degrading both mediumand long-chain alkanes in this environment.

\section{Near bottom water isolates degrade alkanes under physiologically relevant conditions}

To complement genetic predictions that NBW bacteria degrade hydrocarbons, we isolated 38 axenic alkane-degrading strains from NBW on alkane-dependent medium. Most isolates were Oceanospirillales and mainly affiliated with Alcanivorax, including A. jadensis ZYF844, A. venustensis ZYF848, and A. dieselolei ZYF854 (Additional file 1: Figure S13 and Table S6). The three Alcanivorax isolates showed 99.6$100 \% 16 \mathrm{~S}$ rRNA gene similarity to sequences derived from high-throughput amplicon sequencing, indicating that they represent indigenous NBW species. These three isolates degraded a wide range $\left(\mathrm{C}_{18}-\mathrm{C}_{26}\right)$ of $n$-alkanes at $4{ }^{\circ} \mathrm{C}$ and $0.1 \mathrm{MPa}$ (atmospheric pressure) (Fig. 5a). Notably, they could utilize $n$-eicosane $\left(C_{20}\right)$ as the sole carbon source at physiologically relevant temperature $\left(4^{\circ} \mathrm{C}\right)$ and pressure $(60 \mathrm{MPa})$ with the strain ZYF844 displaying the highest degradation rate (Fig. 5b).

O. marinus DSM 24913 was tested for hydrocarbon degradation activity, since no Oleibacter species was isolated from NBW (despite repeated attempts with alkane-dependent media and Marine Broth under $4 / 16^{\circ} \mathrm{C}$ and $0.1 / 60 \mathrm{MPa}$ ) and $O$. marinus is the only cultured species available in this genus. Oleibacter MAG 01, the most abundant clade in NBW, demonstrated 99.0\% 16S rRNA gene sequence identity to $O$. marinus DSM 24913. Moreover, MAG 01 contained a putative $\operatorname{alkB}$ and two $\operatorname{alm} A$ genes, which encoded enzymes with $>99.5 \%$ amino acid identity to those of O. marinus DSM 24913 [12], and up to $34.0 \%$ and $49.7 \%$ identity to functionally characterized AlkB and AlmA from A. dieselolei, respectively $[14,23]$. MAG 01 also harbored 11 putative MCP genes (O. marinus DSM 24913 possessed 14 MCP genes), with up to $43.9 \%$ amino acid identity to the functionally confirmed $A$. dieselolei MCP involved in sensing alkanes [14].

Unlike NBW Alcanivorax species, O. marinus DSM 24913 could not degrade hydrocarbons at $4{ }^{\circ} \mathrm{C}$ and $60 \mathrm{MPa}$, but it displayed a high rate of hydrocarbon degradation in cultures fed on $n$-eicosane at $16^{\circ} \mathrm{C}$ and atmospheric pressure (Fig. 5b). This implies that NBW Oleibacter species, such as MAG 01, have evolved to withstand high pressure and low temperature typical of hadal conditions. Thus, we propose that the NBW Oleibacter species may represent novel and hadal-specific ecotypes despite their high $16 \mathrm{~S}$ rRNA gene (i.e., 99.0\% identity) and genome sequence (98.6\% average nucleotide identity) identity to O. marinus DSM 24913. A similar phenomenon was shown for Alteromonas macleodii species, which are phylogenetically divided into "surface" or "deep" ecotypes (recently a new species A. mediterranea was separated [24]), according to seawater depth, despite sharing > 99\% 16S rRNA gene similarity [25]. In support of bioinformatic predictions, $n$-alkanes can be utilized as a carbon and/or energy source by all tested NBW Oceanospirillales isolates under high pressure and low temperature, and O. marinus, representative of the dominant Oleibacter genus in NBW under atmospheric pressure at $16^{\circ} \mathrm{C}$.

\section{Potential alkane accumulation at deeper depths and production in sediments in the Mariana Trench}

To study the hydrocarbon sources that may support this population, we investigated alkane concentrations in sinking particle $(2000,4000$, and $6000 \mathrm{~m}$; Fig. 6a and Additional file 1: Table S7) and surface sediment
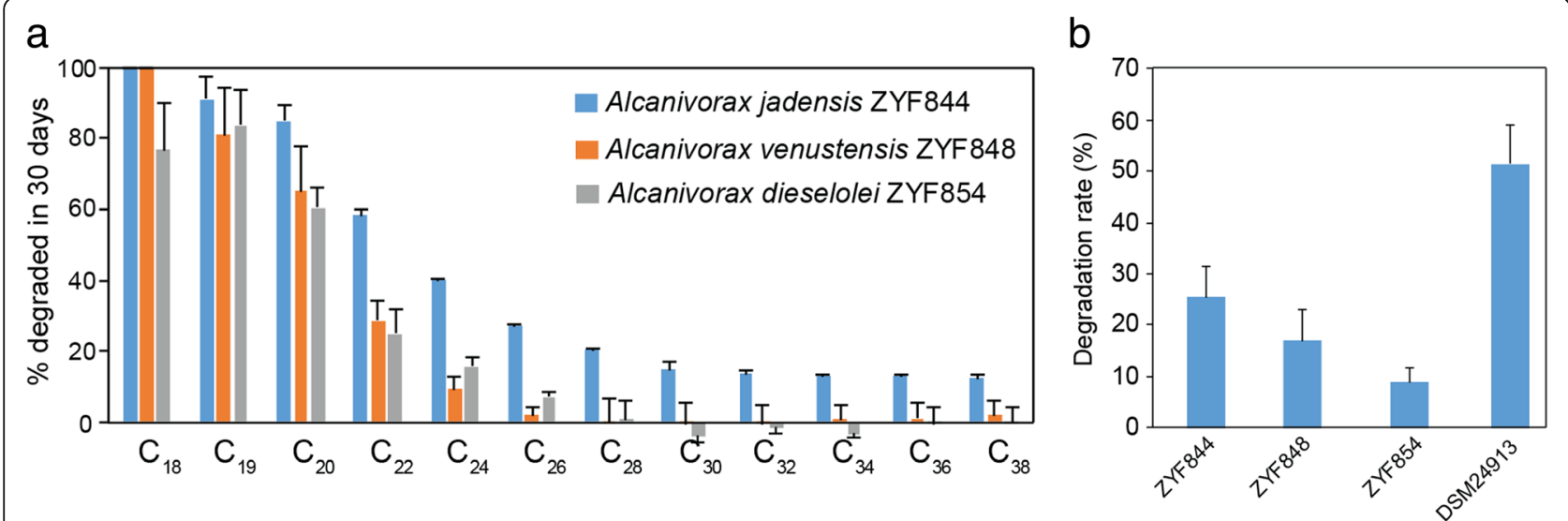

Fig. 5 Alkanes are degraded by Oceanospirillales isolates. a Bacterial degradation rate of $\mathrm{C}_{18 \text { - } 38}$ n-alkanes at $4{ }^{\circ} \mathrm{C}, 0.1 \mathrm{MPa}$ for 30 days. $\mathbf{b}$ n-eicosane at $4{ }^{\circ} \mathrm{C}$, $60 \mathrm{MPa}$ for 20 days for Alcanivorax strains (ZYF844, ZYF848, ZYF854), and $16^{\circ} \mathrm{C}, 0.1 \mathrm{MPa}$ for 12 days for 0. marinus DSM 24913 


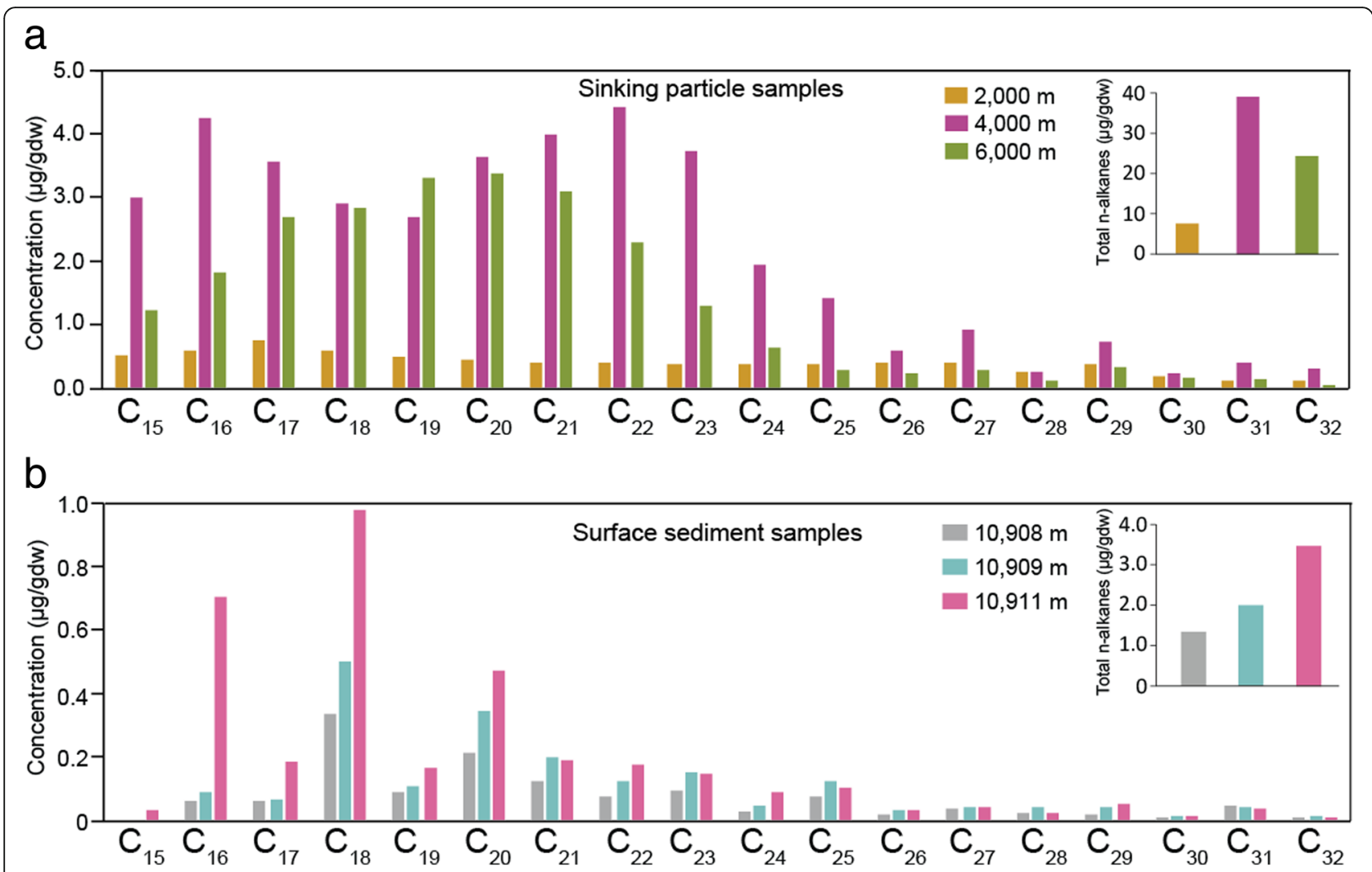

Fig. 6 Alkanes accumulate at lower depths. a Sinking particle samples. b Surface sediment samples. Total $n$-alkane concentrations of each sample are shown in the upper-right corner of $\mathbf{a}$ and $\mathbf{b}$

samples (Fig. 6b). Total concentrations of $n$-alkanes (in the range of $n-C_{15}$ to $n-C_{32}$ ) in sinking particles increased from $2000(7.2 \mu \mathrm{g} / \mathrm{gdw})$ to $4000(39.0 \mu \mathrm{g} / \mathrm{gdw})$, but then decreased slightly at $6000 \mathrm{~m}(24.2 \mu \mathrm{g} / \mathrm{gdw})$. These values are comparable or slightly higher than hydrocarbon concentrations $(8.3-37 \mu \mathrm{g} / \mathrm{g}$; dominated by $n$-alkanes) reported for sinking particles from abyssal waters of the northeastern Pacific Ocean [26]. The unique funnel-shaped geomorphology of the trenches (Additional file 1: Figure S1) promotes the accumulation of particulate organic matter sinking from the surface [27], including possible terrestrial organic matter sources [27], facilitated by lateral transportation from trench rims and slopes that is often triggered by earthquakes [28]. Considering this, we hypothesize that $n$-alkane hydrocarbons maintain high concentrations, or even increase, at depths below $6000 \mathrm{~m}$. Unfortunately, we were unable to analyze alkane concentrations in sinking particle samples at deeper depths, so further work is required to test this hypothesis.

To determine the sources of $n$-alkanes in hadal surface sediments at depths of 10,908, 10,909, and 10,911 m (Fig. 6b and Additional file 1: Table S7), we investigated their distribution and concentrations (total $n$-alkane concentration averaged $2.3 \mu \mathrm{g} / \mathrm{gdw}$ ). Interestingly, higher concentrations of $n-C_{18}$ and $n-C_{20}$ (and $n-C_{16}$ in one sample) compared to $n$ - $C_{17 / 19 / 21}$ alkanes (Fig. $6 \mathrm{~b}$ ) were observed. The predominance of even-chain alkanes has been reported previously by other studies, e.g., in sediments from the Black and Mediterranean Seas, Arabian Gulf, and Cariaco Trench [29], and from the Mariana Trench sediments at depths of $4900-7068 \mathrm{~m}$ [30]. These were markedly different from those profiles seen in the sinking particle samples, suggesting that even-chain alkanes in hadal surface sediments have a very different source and are likely synthesized in situ and/or released from subsurface sediments. To provide further evidence for the origin of these compounds, we investigated the carbon and hydrogen isotope compositions of $n-C_{16}$ and $n-C_{18}$ alkanes (Fig. 7). The $\delta^{13} \mathrm{C}$ values of $n-\mathrm{C}_{16}$ and $n-\mathrm{C}_{18}$ alkanes ranged from -30.2 to $-28.7 \%$, similar to those reported by Guan et al. [30], which are not very source specific as these values fall within the range of isotopic compositions of hydrocarbons derived both from petroleum as well as from autotrophic and heterotrophic organisms [31]. However, more crucially, the $\delta^{2} \mathrm{H}$ values of $n-\mathrm{C}_{16}$ and $n-\mathrm{C}_{18}$ alkanes are much more informative. They varied from -79 to $-93 \%$, which are higher than those typically assigned to petroleum sources (- 90 to $-150 \%$ [32]) and fall within the range of lipid/water ${ }^{2} \mathrm{H} /{ }^{1} \mathrm{H}$ fractionations reported for 


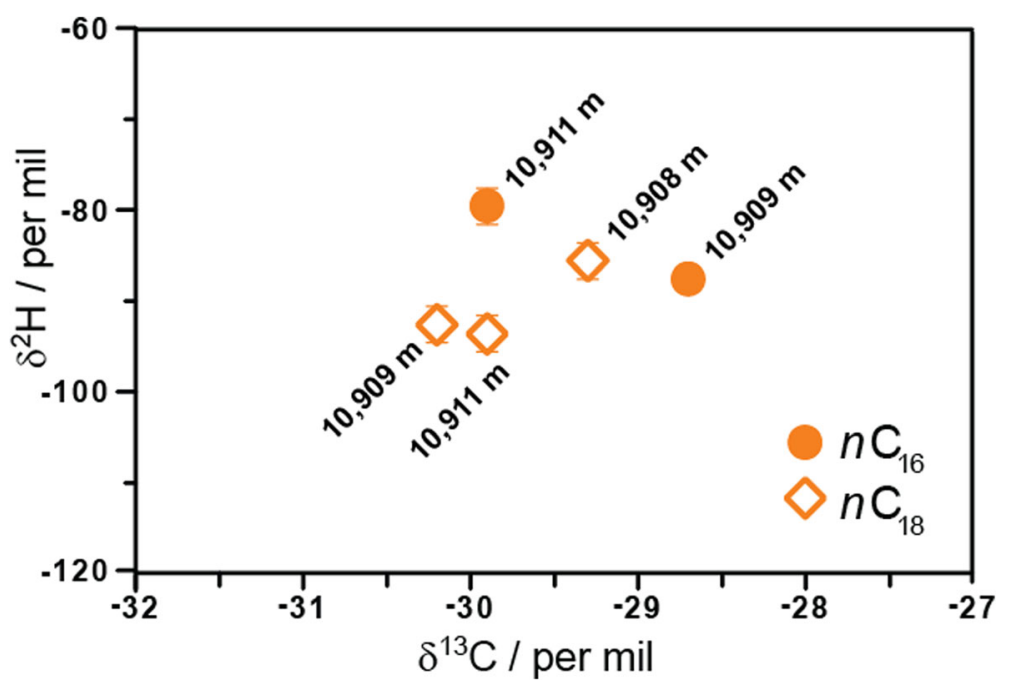

Fig. 7 The carbon and hydrogen isotopic compositions of $n-C_{16}$ and $n-C_{18}$ alkanes from hadal surface sediments. The errors are based on duplicate measurements

heterotrophic organisms (-150\%o and higher [33]) assuming the $\delta^{2} \mathrm{H}$ of water is ca. $0 \%$. These $\delta^{2} \mathrm{H}$ data suggest that $n$-alkanes in the hadal sediments most likely derive from a distinct biological source (e.g., from heterotrophic communities [33]) that results in a smaller hydrogen isotope fractionation. This source differs from that produced by known hydrocarbon-producing marine organisms, predominantly photoautotrophs, which synthesize only odd-C-numbered hydrocarbons [34-36], suggesting that the microbial producers might utilize a different, and still poorly understood biosynthetic pathway.

Given the NBW Alcanivorax isolates were more efficient at degrading $\mathrm{C}_{18}-\mathrm{C}_{20}$ compared to $>\mathrm{C}_{22}$ alkanes (Fig. 5a), it is possible that these bacteria have evolved to take advantage of these specific hydrocarbons. Thus, this unknown biological source of $n-\mathrm{C}_{16}, n-\mathrm{C}_{18}$, and $n-\mathrm{C}_{20}$ hydrocarbons in the surface sediments at the bottom of the trench may contribute, with sinking particle hydrocarbons, to support the observed NBW hydrocarbon-degrading microbial population. Further work, involving turnover rate measurements, is likely required to establish this hypothesis. A similar hydrocarbon cycle is likely present in surface waters, where hydrocarbon-degrading bacteria are supported by alkanes synthesized by cyanobacteria and algae [34]. Currently, it is uncertain if these hydrocarbons are produced by microbes only found in the sediments or whether they are widespread in NBW, since we were unable to study their prevalence in NBW samples and the enzymes synthesizing even-chain alkanes have not been identified.

\section{Conclusions}

In summary, this study demonstrates the highly stratified metabolic potential of the microbial community in the hadal zone of the Mariana Trench. The deepest waters
(> 10,000 $\mathrm{m}$ ) are enriched with alkane-degrading bacteria of Oceanospirillales at a proportion higher than observed anywhere else on Earth, which are transcribing alkane-degrading genes. The study raises important questions that warrant further investigation in this unique environment. Which sources of alkanes support microorganisms in the deepest waters on Earth: novel biological alkanes identified in deep hadal sediments or alkanes derived from other sources (e.g., surface water photoautotrophs and/or petroleum), or both? Further, what causes the abrupt and unexpected shift in metabolic potential towards hydrocarbon degradation at depths below 10,000 $\mathrm{m}$ and are such shifts common in other deep trench environments?

\section{Methods}

\section{Sample collection}

Seawater at 0 (cast \#101, $200 \mathrm{~L}$ ), 4000 (cast \#102, $200 \mathrm{~L}$ ), 9600 (cast \#103, $96 \mathrm{~L}$ ), 10,400 (cast \#104, $96 \mathrm{~L}$ ), and 10,500 m (cast \#105, $96 \mathrm{~L}$ ) was collected using Niskin bottles from the Challenger Deep of the Mariana Trench $\left(11^{\circ} 20.605^{\prime} \mathrm{N}, 142^{\circ} 19.557^{\prime} \mathrm{E}, 10,800 \mathrm{~m}\right)$ aboard the R/ V Dong Fang Hong 2 in September 2016. Collection points are shown in Additional file 1: Figure S1 [37]. Water salinity and temperature (Additional file 1: Table S2) were recorded by CTD. For each depth, water samples from three or four Niskin bottles were pooled and filtered onto one membrane. It took $4-5 \mathrm{~h}$ to retrieve seawater from the deepest depth $(10,500 \mathrm{~m})$. Upon resurfacing, biomass collection was completed within $1 \mathrm{~h}$. Seawater was filtered serially through $3 \mu \mathrm{m}$ (TSTP, 142 $\mathrm{mm}$, Millipore) and $0.22 \mu \mathrm{m}$ (GTTP, $142 \mathrm{~mm}$, Millipore) polycarbonate membranes. The communities collected on the $3-\mu \mathrm{m}$ and $0.22-\mu \mathrm{m}$ filters were designated as 
particle-associated and free-living fractions, respectively. All filters were stored in liquid nitrogen onboard and at $-80^{\circ} \mathrm{C}$ in the laboratory. Sinking particles were collected at the same location as seawater using time series sediment traps (McLane Research Laboratories, Mark-7) deployed at three depths $(2000 \mathrm{~m}, 4000 \mathrm{~m}$, and $6000 \mathrm{~m}$ ) from January to September 2016. The surface sediment samples were collected from the Mariana Trench $\left(11^{\circ}\right.$ $\left.19.5132^{\prime} \mathrm{N}, 142^{\circ} 11.2906^{\prime} \mathrm{E}\right)$ at a depth of $\sim 10,910 \mathrm{~m}$ during research cruise TS-03 in January 2017 using the lander "TianYaHao" aboard the R/V TAN SUO YI HAO (see details in Additional file 2: Supplementary method).

\section{DNA and RNA extraction}

DNA was extracted from water samples of both fractions at all five depths as previously described [38]. Briefly, biomass was washed from half of each filter using $15-\mathrm{ml}$ extraction buffer $(100 \mathrm{mM}$ Tris- $\mathrm{HCl}[\mathrm{pH}$ 8.0], $100 \mathrm{mM}$ sodium EDTA [pH 8.0], $100 \mathrm{mM}$ sodium phosphate [pH 8.0], $1.5 \mathrm{M} \mathrm{NaCl}, 1 \%$ CTAB) and then centrifuged at $5000 \times g$ for $20 \mathrm{~min}$ at room temperature. The concentrated biomass was ground within liquid nitrogen. Proteinase $\mathrm{K}$ and SDS were added in sequence and incubated at $37^{\circ} \mathrm{C}$ and $65^{\circ} \mathrm{C}$, respectively, followed by phenol-chloroform extraction. DNA was precipitated with 0.6 volume of isopropanol, washed with $70 \%$ ethanol, air dried, and dissolved in TE buffer. The concentration and integrity of genomic DNA were analyzed by Qubit fluorometer and agarose gel electrophoresis, respectively. RNA was extracted using the Trizol reagent and cleaned using the Direct-zol RNA MiniPrep kit. DNA removal was performed using the TURBO DNA-free kit. Successful DNA removal was confirmed by $16 \mathrm{~S}$ rRNA gene PCR. cDNA was generated using the Promega M-MLV reverse transcriptase.

\section{Metagenomic sequencing, 16S rRNA gene high- throughput sequencing, and clone library construction}

Nine DNA samples (each greater than $1.5 \mu \mathrm{g}$ ), except for the particle-associated fraction of $9600 \mathrm{~m}$ due to an insufficient quantity of DNA, were sent to BGI (BGI, Shenzhen, China) for metagenomic sequencing. Libraries were prepared without any amplification step for each sample. Metagenomic shotgun sequencing was performed on the Illumina HiSeq X-Ten platform, with $2 \times$ 150-bp paired-end reads. Primers 515F and 806R (Additional file 1: Table S8) were used to amplify the V4 region of the 16S rRNA gene, and DNA extracted from three membranes were treated as triplicate. Sequencing was performed on the Illumina Miseq PE300 platform (MiSeq Reagent Kit v3) at Majorbio BiFo-Pharm Technology Co., Ltd., Shanghai, China. Sequences were processed with the pipeline of UPARSE [39]. Operational taxonomic units (OTUs) were clustered at a 97\% similarity level and taxonomically assigned against the SILVA SSU reference database (release 132). To examine the phylogenetic relationship between bacterial isolates and environmental sequences, a clone library was constructed using DNA from the FL10500 sample with primers B8F and B1510R (Additional file 1: Table S8). PCR products were inserted into pUCm-T vectors and cloned into Escherichia coli JM109. Positive clones were checked with PCR using primers M13F/R. Correct clones were sequenced at BGI (Qingdao, China) and taxonomically assigned using the EzTaxon-e server (https://www.ezbiocloud.net).

\section{Quantitative PCR and reverse transcription qPCR}

The abundance of bacterial 16S rRNA genes was quantified using quantitative PCR (qPCR) with primers Eub338F and Eub518R (Additional file 1: Table S8). Genomic DNA extracted from 10,500 m was used as a template to amplify $16 \mathrm{~S}$ rRNA genes. PCR products were purified using a Gel Extraction Kit (Omega), ligated with pUCm-T vector, and then transformed into competent E. coli JM109 cells for sequencing. The sequence of target genes was submitted to the EzTaxon-e server (https://www.ezbiocloud.net) and identified as Ulvibacter sp. (Flavobacteria). The confirmed plasmid was extracted using a Plasmid Mini Kit (Omega) and digested with restriction enzyme XhoI. The linear plasmid was purified using a Gel Extraction Kit (Omega) and was serially diluted to construct standard curves (concentration ranged from $2.91 \times 10^{2}$ to $2.91 \times 10^{7}$ copies/L). The reverse transcription qPCR (RT-qPCR) standards for the $\operatorname{alkB}$ and $\operatorname{alm} A$ gene (Additional file 1: Table S8) were prepared as detailed in the above description for the $16 \mathrm{~S}$ rRNA gene. qPCR was performed on the StepOnePlus Real-Time PCR System based on SYBR Green I.

\section{Assembly and binning}

The reads that contain more than $10 \%$ of undefined bases and more than $40 \%$ of low-quality bases, and had a length of more than 15 bases matching to the adapters were removed. After filtering, clean data ranging in size from 13.67 to $16.54 \mathrm{~Gb}$ was obtained from each sample, and the average Q30 of each sample was above 93\%, indicating that the trimmed dataset was of high quality. High-quality reads were assembled using SOAPdenovo2 [40] with a kmer size of 49 . Contigs shorter than $500 \mathrm{bp}$ were discarded. Gene prediction was performed using MetaGeneMark [41] with default parameters (http:// exon.gatech.edu/GeneMark/meta_gmhmmp.cgi).

Metagenomic binning was performed on four bottom water samples (FL10400, PA10400, FL10500, and PA10500). The initial paired-end reads from these four samples were co-assembled using IDBA-UD [42]. Subsequently, these reads were mapped to the final contigs 
with BWA [43]. Contigs were grouped into MAGs based on empirical probabilistic distances of genome abundance and tetranucleotide frequency by using program MetaBAT2 [44]. Completeness and contamination of MAGs were assessed using CheckM [45], and MAGs with a completeness above $80 \%$ and contamination lower than $10 \%$ were considered for further analysis. PhyloPhlAn [46] was used to determine the phylogeny of MAGs, following by the average nucleotide identity (ANI) calculated to further confirm the taxonomy. The relative abundance of each MAG was calculated by mapping each of them to the raw reads. Gene calling of the MAGs was carried out using the RAST server [47]. All the predicted genes were searched against the SEED subsystems, COG (ftp://ftp.ncbi.nlm.nih.gov/pub/COG/), and KEGG (http://www.kegg.jp/kegg/) databases.

\section{Taxonomic assignment and functional characterization}

Genes were clustered to remove redundant sequences using CD-Hit [48] at the 95\% identity and 90\% coverage. The gene annotation was done using BLASTp with an $e$-value cutoff of $10^{-5}$ against KEGG, COG, SEED, and NCBI-nr (released August 2016) databases for functional and taxonomic analysis, and only the best hits were retained. Taxonomy assignment was performed in MEGAN software [49] (version 4.6) based on the BLAST results of nr database using the lowest common ancestor (LCA) algorithm. To verify the taxonomic assignment results, metagenomic reads were mapped onto sequences of the SILVA SSU Ref NR99 database (release 132) using the BBMap package (http://sourceforge.net/ projects/bbmap/) with $97 \%$ identity. The sequence coverage, which is the total length of mapped reads divided by the reference sequence length, was determined. The relative abundance of each taxon was calculated from the sequence coverage of each taxon $(E)$ and the total sequence coverage $(T)$ as $E / T \times 100 \%$. Gene abundance was normalized by the number of the mapped reads of the target gene to the gene length. The taxa that were significantly enriched in the four NBW samples were described. Averaged abundances across the four NBW samples were provided. Standard deviations were calculated to account for within-group differences.

The marker genes (Additional file 3) for the major known types of aliphatic hydrocarbon-degradation enzymes, i.e., methane monooxygenase (MMO), gaseous short-chain alkane $\left(\mathrm{C}_{2}-\mathrm{C}_{4}\right)$ monooxygenase, mediumchain alkane degradation enzymes (AlkB and cytochrome $\mathrm{P} 450$ monooxygenases, degrading $\mathrm{C}_{5}-\mathrm{C}_{26}$ ), long-chain alkane monooxygenase (represented by AlmA, degrading $\mathrm{C}_{14}-\mathrm{C}_{36}$ ), and other relevant genes potentially involved in hydrocarbon degradation were searched against the metagenomic data using BLASTp with an $e$-value cutoff of $10^{-5}$. An identity value of $40 \%$ was used for AlkB, cytochrome P450, and AlmA to increase the possibility of capturing the real functional proteins. All MMO sequences retrieved from the BLASTp results were further annotated in the NCBI-nr database, since they all showed low identity $(<42.9 \%)$ compared to marker genes. Only those sequences with top hits to methane monooxygenase in the NCBI-nr database were finally kept. Sequences of $a l k B$ and cytochrome P450 were retrieved from a functional gene pipeline (http://fungene.cme.msu.edu/). Short-chain (C2-C4) hydrocarbon monooxygenase and long-chain alkane monooxygenase were retrieved from NCBI according to $\mathrm{Li}$ et al. [50] and Wang and Shao [14], respectively. Reference sequences of methane monooxygenase were downloaded from the RefSeq database at NCBI. Genes involved in three intermediates (catechol, protocatechuate, and gentisate) of the aromatic degradation pathway were retrieved from the GeoChip 4.6 (http://www.ou.edu/ieg/tools) and RefSeq database at NCBI (Additional file 3). Statistics where applied were examined with the Wilcox ranking test.

\section{Bacterial cultivation and $n$-alkane degradation}

Water samples $(10,400 \mathrm{~m})$ were enriched using MMC medium $\left(24 \mathrm{~g} \mathrm{NaCl}, 7.0 \mathrm{~g} \mathrm{MgSO}_{4} \cdot 7 \mathrm{H}_{2} \mathrm{O}, 1 \mathrm{~g} \mathrm{NH}_{4} \mathrm{NO}_{3}\right.$, $0.7 \mathrm{~g} \mathrm{KCl}, 2.0 \mathrm{~g} \mathrm{KH}_{2} \mathrm{PO}_{4}, 3.0 \mathrm{~g} \mathrm{Na}_{2} \mathrm{HPO}_{4}$, and $10 \mathrm{ml}$ of a trace element solution, $\mathrm{pH} 7.5$ ) with hexadecane as a sole carbon source and cultivated at $10^{\circ} \mathrm{C}$, atmospheric pressure on a rotary shaker $(170 \mathrm{rpm})$. A total of $38 \mathrm{bac}-$ terial strains were obtained. Taxonomic assignment was determined by using the EzBioCloud server (http:// www.ezbiocloud.net/). Three Alcanivorax strains (A. jadensis ZYF844, A. venustensis ZYF848, and $A$. dieselolei ZYF854) were chosen for $n$-alkane degradation tests. Incubations were performed in $50 \mathrm{ml}$ of $\mathrm{MMC}$ medium supplemented with $10 \mu \mathrm{l}$ of alkane mixture at $4{ }^{\circ} \mathrm{C}$, atmospheric pressure for 30 days. After confirmation that these species can utilize alkanes at low temperature, we further tested whether they could degrade $n$-alkanes at high pressure. The strains were incubated in $5 \mathrm{ml}$ of MMC medium supplemented with $5 \mathrm{mg}$ of $n$-eicosane at $4{ }^{\circ} \mathrm{C}, 60 \mathrm{MPa}$ for 20 days. High pressure incubations were conducted in stainless steel reactors $(380 \mathrm{ml}$, maximum pressure $60 \mathrm{MPa}$; Nantong Feiyu Oil Science and Technology Exploitation, China). Pressure was delivered by water using a manual pump. Once the incubation was finished, the remaining alkanes were extracted immediately using dichloromethane and analyzed using an Agilent 7890B Gas Chromatography (GC) with an FID detector. Oleibacter marinus DSM 24913 (=NBRC 105760) bought from the Marine Culture Collection of China was also tested for $n$-alkane degradation at $4{ }^{\circ} \mathrm{C}$, $60 \mathrm{MPa}$, but demonstrated poor growth. Thus, this strain was incubated at $16^{\circ} \mathrm{C}$, atmospheric pressure with 
$n$-eicosane as a sole carbon source (see details in Additional file 2: Supplementary method).

\section{Analysis of $\boldsymbol{n}$-alkanes}

The remaining alkanes in 50- or 5-ml bacterial cultures were extracted using 10 or $2 \mathrm{ml}$ of dichloromethane and analyzed using an Agilent 7890B Gas Chromatograph (GC) with an FID detector. Two further rounds of extraction were performed. A deuterated alkane $\left(\mathrm{C}_{24} \mathrm{D}_{50}\right)$ was used as an internal recovery standard (see details in Additional file 2: Supplementary method). The $n$-alkane analysis procedure for sinking particle and surface sediment samples was the same as that of the bacterial cultures except for extraction. Sinking particles and surface sediment samples were first freeze-dried and ground using a mortar and pestle. In order to obtain sufficient $n$-alkane yields from sinking particles at each depth, we combined the samples collected at nine time points (from January to September). Alkanes were extracted from $700 \mathrm{mg}$ of sinking particles (for each depth) and $5.0 \mathrm{~g}$ surface sediments using $30 \mathrm{ml}$ dichloromethane/ methanol $(9: 1, v / v)$ for $10 \mathrm{~min}$. This procedure was repeated four times and the extracts were combined. Dichloromethane and hexane without sample were used as a blank. All the extraction process was conducted in a clean room, and all the glassware were baked at $550^{\circ} \mathrm{C}$ for $12 \mathrm{~h}$ to remove any organic matter. The alkanes were not analyzed in the original water samples since we were not expecting to find such a large proportion of hydrocarbon degraders below 10,000 m.

\section{Analysis of carbon and hydrogen isotopic compositions of $n$-alkanes}

Once isolated, biomarker $n$-alkanes were analyzed first by gas chromatography (Thermo Scientific Trace 1310) with a flame ionization detector (GC-FID) fitted to a 30-m TG-5SilMS $(0.25 \mathrm{~mm} \times 0.25 \mu \mathrm{m})$ fused silica column. Sample aliquots of $1 \mu \mathrm{l}$ were injected by programmed temperature vaporizing (PTV) injector at $320^{\circ}$ $\mathrm{C}$ through a split/splitless silcosteel inlet liner. The chromatograph oven was ramped from $60^{\circ} \mathrm{C}(1 \mathrm{~min})$ to $320^{\circ}$ $\mathrm{C}(20 \mathrm{~min})$ at $6^{\circ} \mathrm{C} \mathrm{min}^{-1}$. Helium was used as a carrier at $2 \mathrm{ml} \mathrm{min}^{-1}$, and the detector was set to a constant temperature of $320^{\circ} \mathrm{C}$. Stable isotope measurements of biomarker $n$-alkanes were measured by gas chromatography combustion $\left(\delta^{13} \mathrm{C}\right)$ or pyrolysis $\left(\delta^{2} \mathrm{H}\right)$ isotope ratio monitoring mass spectrometry (GC-C-irMS or GC-pyr-irMS, respectively) with a Thermo Scientific Trace 1310 GC with split/splitless injector and TriPlus RSH liquid autosampler coupled to a Delta V Plus MS (see details in Additional file 2: Supplementary method).

\section{Additional files}

Additional file 1: Supplementary figures and tables (DOCX $3821 \mathrm{~kb}$ )

Additional file 2: Supplementary methods (DOCX $33 \mathrm{~kb}$ )

Additional file 3: Accession numbers of protein sequences used as query sequence against the metagenomic datasets in this study (XLSX $12 \mathrm{~kb}$ )

\section{Acknowledgements}

We would like to thank all of the scientists and crews on the RN Dong Fang Hong 2 and RN TAN SUO YI HAO for their assistance with sampling during the cruise. We also thank Prof. Curtis Suttle from the University of British Columbia, Canada and Dr. Boyd McKew from the University of Essex for critical reading and discussion. We thank Dr. James V. Gardner from the Center for Coastal \& Ocean Mapping, University of New Hampshire, for providing Additional file 1: Figure S1.

\section{Funding}

This work was funded by the National Natural Science Foundation of China (91751202, 41730530, 41476112 and 41506154), Fundamental Research Funds for the Central Universities (201762009), Scientific and Technological Innovation Project of Qingdao National Laboratory for Marine Science and Technology (2016ASKJ14 and 2016ASKJ15), National Program on Global Change and Air-Sea Interaction (GASI-02-PAC-ST-MSwin) and the Strategic Priority Research Program from the Chinese Academy of Sciences (XDB06010203). JDT was funded by Natural Environmental Research (NERC) grants NERC standard grants NE/S001352, NE/P012671 and NE/N002385.

\section{Availability of data and materials}

Sequence data for metagenome and 165 rRNA reads have been deposited in the NCBI Sequence Read Archive under accession numbers SRP119520 and SRP119680, respectively. The Oceanospirillales MAGs have been deposited at GenBank under the accession numbers QAGL00000000 (MAG 01), PDUK00000000 (MAG 78), PDUL00000000 (MAG 5.60), PDUM00000000 (MAG 12) and PZPK00000000 (MAG 156).

\section{Authors' contributions}

$\mathrm{X}-\mathrm{HZ}$ designed the experiments and analyzed the data. JT designed the cruise and the large-volume water sampler. $J L$ and $Y Z$ collected the water samples and analyzed the environmental sequence data. $Y Z$ extracted the community DNA, isolated the strains from seawater, and detected the $n$-alkane degradation capacity. $H L, M L, Y L, M Y$, and $H Z$ performed the metagenomic binning and pathway reconstruction. $X W, M Y, M Z$, and $Y Z$ measured the $n$-alkanes quantity. YX analyzed the environmental factors. WZ collected the sediment samples. NP and $C M$ performed the compound-specific stable isotope measurements and interpreted $\delta^{13} \mathrm{C}$ and $\delta^{2} \mathrm{H}$ data. SZ and DS extracted the RNA from seawater and did the RT-qPCR. DJL-S, NP, and JDT provided critical ideas for interpreting the genomic and $n$-alkane distribution data. $X-H Z, J L, Y Z, D J L-S, J D T$, and NP wrote the manuscript. All authors edited and approved the final manuscript.

Ethics and consent for publication

To carry out sampling, the authors received a 'Research and Training Permit for the Exclusive Economic Zone of the Federated States of Micronesia' issued by the National Oceanic Resource Management Authority - Federated States of Micronesia.

\section{Competing interests}

The authors declare that they have no competing interests.

\section{Publisher's Note}

Springer Nature remains neutral with regard to jurisdictional claims in published maps and institutional affiliations.

\section{Author details}

${ }^{1}$ MOE Key Laboratory of Marine Genetics and Breeding, College of Marine Life Sciences, Ocean University of China, Qingdao 266003, China. ${ }^{2}$ Laboratory for Marine Ecology and Environmental Science, Qingdao National Laboratory for Marine Science and Technology, Qingdao 266237, China. ${ }^{3}$ Key Laboratory of Marine Chemistry Theory and Technology, Ministry of Education, Qingdao 266100, China. ${ }^{4}$ Institute for Advanced Study, Shenzhen University, Shenzhen 
518060, China. ${ }^{5}$ School of Environmental Sciences, University of East Anglia, Norwich NR4 7TJ, UK. ${ }^{6}$ School of Biological Sciences, University of East Anglia, Norwich NR4 7TJ, UK. ' Lyell Centre, Heriot-Watt University, Edinburgh EH14 4AS, UK. ${ }^{8}$ Laboratory of Deep Sea Microbial Cell Biology, Institute of Deep Sea Science and Engineering, Chinese Academy of Sciences, Sanya 572000, China. ${ }^{9}$ Key Laboratory of Physical Oceanography, Ministry of Education, Ocean University of China, Qingdao 266100, China. ${ }^{10}$ Marine Dynamic Process and Climate Function Laboratory, Qingdao National Laboratory for Marine Science and Technology, Qingdao 266237, China.

\section{Received: 25 November 2018 Accepted: 22 February 2019 Published online: 12 April 2019}

\section{References}

1. Nunoura T, Takaki Y, Hirai M, Shimamura S, Makabe A, Koide O, et al. Hadal biosphere: insight into the microbial ecosystem in the deepest ocean on Earth. Proc Natl Acad Sci U S A. 2015;112:E1230-6.

2. Tarn J, Peoples LM, Hardy K, Cameron J, Bartlett DH. Identification of freeliving and particle-associated microbial communities present in hadal regions of the Mariana Trench. Front Microbiol. 2015;7:665.

3. Tian J, Fan L, Liu H, Liu J, Li Y, Qin Q, et al. A nearly uniform distributional pattern of heterotrophic bacteria in the Mariana Trench interior. Deep Sea Res Part 1 Oceanogr Res Pap. 2018;142:116-26.

4. Eloe EA, Shulse CN, Fadrosh DW, Williamson SJ, Allen EE, Bartlett DH. Compositional differences in particle-associated and free-living microbial assemblages from an extreme deep-ocean environment. Environ Microbio Rep. 2011;3:449-58.

5. Nunoura T, Hirai M, Yoshida-Takashima Y, Nishizawa M, Kawagucci S, Yokokawa T, et al. Distribution and niche separation of planktonic microbial communities in the water columns from the surface to the hadal waters of the Japan Trench under the Eutrophic Ocean. Front Microbiol. 2016;7:1261.

6. Peoples LM, Donaldson S, Osuntokun O, Xia Q, Nelson A, Blanton J, et al. Vertically distinct microbial communities in the Mariana and Kermadec trenches. PLoS One. 2018;13:e0195102.

7. Lacey NC, Rowden AA, Clark MR, Kilgallen NM, Linley T, Mayor DJ, et al. Community structure and diversity of scavenging amphipods from bathyal to hadal depths in three South Pacific Trenches. Deep Sea Res Part 1 Oceanogr Res Pap. 2016;111:121-137.

8. León-Zayas R, Novotny M, Podell S, Shepard CM, Berkenpas E, Nikolenko S, et al. Single cells within the Puerto Rico trench suggest hadal adaptation of microbial lineages. Appl Environ Microbiol. 2015;81:8265-76.

9. Sun $\mathrm{DL}$, Jiang $X, \mathrm{Wu} \mathrm{QL}$, Zhou NY. Intragenomic heterogeneity in $16 \mathrm{~S}$ rRNA genes causes overestimation of prokaryotic diversity. Appl Environ Microb. 2013;79:5962-9

10. Uyaguari-Diaz MI, Chan M, Chaban BL, Croxen MA, Finke JF, Hill JE, et al. A comprehensive method for amplicon-based and metagenomic characterization of viruses, bacteria, and eukaryotes in freshwater samples. Microbiome. 2016;4:20.

11. Mattick JS. Type IV pili and twitching motility. Annu Rev Microbiol. 2002;56: 289-314.

12. Teramoto $M$, Ohuchi $M$, Hatmanti A, Darmayati $Y$, Widyastuti $Y$, Harayama $S$, et al. Oleibacter marinus gen. nov., sp. nov., a bacterium that degrades petroleum aliphatic hydrocarbons in a tropical marine environment. Int J Syst Evol Microbiol. 2011;61:375-80

13. Liu J, Bacosa HP, Liu Z. Potential environmental factors affecting oildegrading bacterial populations in deep and surface waters of the northern Gulf of Mexico. Front Microbiol. 2017;7:2131.

14. Wang WP, Shao ZZ. The long-chain alkane metabolism network of Alcanivorax dieselolei. Nat Commun. 2014:5:5755.

15. Rivers AR, Sharma S, Tringe SG, Martin J, Joye SB, Moran MA. Transcriptional response of bathypelagic marine bacterioplankton to the Deepwater Horizon oil spill. ISME J. 2013;7:2315-29.

16. Mason OU, Hazen TC, Borglin S, Chain PS, Dubinsky EA, Fortney JL, et al. Metagenome, metatranscriptome and single-cell sequencing reveal microbial response to Deepwater Horizon oil spill. ISME J. 2012;6:1715-27.

17. Hazen TC, Dubinsky EA, DeSantis TZ, Andersen GL, Piceno YM, Singh N, et al. Deep-sea oil plume enriches indigenous oil-degrading bacteria. Science. 2012;330:204-8.

18. Redmond MC, Valentine DL. Natural gas and temperature structured a microbial community response to the Deepwater Horizon oil spill. Proc Natl Acad Sci U S A. 2012;109:20292-7.
19. Valentine DL, Kessler JD, Redmond MC, Mendes SD, Heintz MB, Farwell C, et al. Propane respiration jump-starts microbial response to a deep oil spill. Science. 2010;330:208-11.

20. Hu P, Dubinsky EA, Probst AJ, Wang J, Sieber CMK, Tom LM, et al. Simulation of Deepwater Horizon oil plume reveals substrate specialization within a complex community of hydrocarbon degraders. Proc Natl Acad Sci U S A. 2017;114:7432-7.

21. Delmont TO, Eren AM. Simulations predict microbial responses in the environment? This environment disagrees retrospectively. Proc Natl Acad Sci U S A. 2017;114:E8947-9.

22. Gutierrez T, Singleton DR, Berry D, Yang T, Aitken MD, Teske A. Hydrocarbon-degrading bacteria enriched by the Deepwater Horizon oil spill identified by cultivation and DNA-SIP. ISME J. 2013;7:2091-104.

23. Liu C, Wang W, Wu Y, Zhou Z, Lai Q, Shao Z. Multiple alkane hydroxylase systems in a marine alkane degrader, Alcanivorax dieselolei B-5. Environ Microbiol. 2011;13:1168-78.

24. Ivanova EP, López-Pérez M, Zabalos M, Nguyen SH, Webb HK, Ryan J, et al. Ecophysiological diversity of a novel member of the genus Alteromonas, and description of Alteromonas mediterranea sp. nov. Antonie Van Leeuwenhoek. 2015;107:119-32.

25. Ivars-Martinez E, D'Auria G, Rodríquez-Valera F, Sânchez-Porro C, Ventosa A, Joint I, et al. Biogeography of the ubiquitous marine bacterium Alteromonas macleodii determined by multilocus sequence analysis. Mol Ecol. 2008;17: 4092-106.

26. Simoneit BRT, Grimait JO, Fischer K, Dymond J. Upward and downward flux of particulate organic material in abyssal waters of the Pacific Ocean. Naturwissenschaften. 1986;73:322-5.

27. Luo M, Gieskes J, Chen LY, Shi XF, Chen DF. Provenances, distribution, and accumulation of organic matter in the southern Mariana Trench rim and slope: implication for carbon cycle and burial in hadal trenches. Mar Geol. 2017:386:98-106.

28. Heeszel DS, Wiens DA, Shore PJ, Shiobara H, Sugioka H. Earthquake evidence for along-arc extension in the Mariana Islands. Geochem Geophy Geosy. 2008:9:12.

29. Grimalt J, Albaigés J. Sources and occurrence of $C_{12}-C_{22} n$-alkane distributions with even carbon-number preference in sedimentary environments. Geochim Cosmochim Acta. 1987;51:1379-84.

30. Guan HX, Chen LY, Luo M, Liu LH, Mao SY, Ge HM, et al. Composition and origin of lipid biomarkers in the surface sediments from the southern Challenger Deep, Mariana Trench. Geosci Front. 2019;10:351-60.

31. Pedentchouk N, Turich C. Carbon and hydrogen isotopic compositions of $n$ alkanes as a tool in petroleum exploration. Geol Soc London Spec Publ. 2018:468:105-25.

32. Li C, Sessions AL, Kinnaman FS, Valentine DL. Hydrogen-isotopic variability in lipids from Santa Barbara Basin sediments. Geochim Cosmochim Acta. 2009;73:4803-23.

33. Zhang X, Gillespie AL, Sessions AL. Large D/H variations in bacterial lipids reflect central metabolic pathways. Proc Natl Acad Sci U S A. 2009;106: 12580-6.

34. Lea-Smith DJ, Biller SJ, Davey MP, Cotton CA, Perez Sepulveda BM, Turchyn $A V$, et al. Contribution of cyanobacterial alkane production to the ocean hydrocarbon cycle. Proc Natl Acad Sci U S A. 2015;112:13591-6.

35. Schirmer A, Rude MA, Li X, Popova E, Del Cardayre SB. Microbial biosynthesis of alkanes. Science. 2010;329:559-62.

36. Sorigué $D$, Légeret $B$, Cuiné S, Blangy S, Moulin S, Billon E, et al. An algal photoenzyme converts fatty acids to hydrocarbons. Science. 2017; 357:903-7.

37. Gardner JV, Armstrong AA, Calder BR, Beaudoin J. So, how deep is the Mariana Trench? Mar Geod. 2014;37:1-13.

38. Zhou J, Bruns MA, Tiedje JM. DNA recovery from soils of diverse composition. Appl Environ Microbiol. 1996;62:316-22.

39. Edgar RC. UPARSE: highly accurate OTU sequences from microbial amplicon reads. Nat Methods. 2013;10:996-8.

40. Luo R, Liu B, Xie Y, Li Z, Huang W, Yuan J, et al. SOAPdenovo2, an empirically improved memory-efficient short-read de novo assembler. Gigascience. 2012;1:18.

41. Zhu W, Lomsadze A, Borodovsky M. Ab initio gene identification in metagenomic sequences. Nucleic Acids Res. 2010;38:e132.

42. Peng Y, Leung HCM, Yiu SM, Chin FYL. IDBA-UD, a de novo assembler for single-cell and metagenomic sequencing data with highly uneven depth. Bioinformatics. 2012;28:1420-8. 
43. Li H, Durbin R. Fast and accurate short read alignment with BurrowsWheeler transform. Bioinformatics. 2009;25:1754-60.

44. Kang DWD, Froula J, Egan R, Wang Z. MetaBAT, an efficient tool for accurately reconstructing single genomes from complex microbial communities. Peerj. 2015;3:e1165.

45. Parks DH, Imelfort M, Skennerton CT, Hugenholtz P, Tyson GW. CheckM, assessing the quality of microbial genomes recovered from isolates, single cells, and metagenomes. Genome Res. 2015;25:1043-55.

46. Segata N, Bornigen D, Morgan XC, Huttenhower C. PhyloPhIAn is a new method for improved phylogenetic and taxonomic placement of microbes. Nat Commun. 2013:4:2304.

47. Overbeek R, Olson R, Pusch GD, Olsen GJ, Davis JJ, Disz T, et al. The SEED and the Rapid Annotation of microbial genomes using Subsystems Technology (RAST). Nucleic Acids Res. 2014;42:D206-14.

48. Li W, Godzik A. Cd-hit, a fast program for clustering and comparing large sets of protein or nucleotide sequences. Bioinformatics. 2006;22:1658-9.

49. Huson DH, Auch AF, Qi J, Schuster SC. MEGAN analysis of metagenomic data. Genome Res. 2007;17:377-86.

50. Li M, Jain S, Baker BJ, Taylor C, Dick GJ. Novel hydrocarbon monooxygenase genes in the metatranscriptome of a natural deep-sea hydrocarbon plume. Environ Microbiol. 2014;16:60-71.

\section{Ready to submit your research? Choose BMC and benefit from:}

- fast, convenient online submission

- thorough peer review by experienced researchers in your field

- rapid publication on acceptance

- support for research data, including large and complex data types

- gold Open Access which fosters wider collaboration and increased citations

- maximum visibility for your research: over $100 \mathrm{M}$ website views per year

At $\mathrm{BMC}$, research is always in progress.

Learn more biomedcentral.com/submissions 